\title{
MENELUSURI KONSEP DAN URGENSI PENDIDIKAN PANCASILA
}

Nova Mulia Putri

E-mail : novamuliaputri17@gmail.com

No BP : 20220136

AKBP STIE “KBP"

\section{PENDAHULUAN}

Pancasila yang berarti lima dasar atau lima asas, adalah nama dasar negara kita, negara republik indonesia. Nama pancasila itu sendiri sebenarnya tidaklah terdapat baik di dalam pembukaan UUD 1945. Namun telah cukup jelas bahwa pancasila yang dimaksud adalah lima dasar negara indonesia, sebagaimana yang tercantum didalam pembukaan UUD 1945 alenia keempat yang berbunyi.

1. Ketuhan yang Maha Esa

2. Kemanusian yang Adil dan Beradap

3. Persatuan indonesia

4.

Kerakyatan Yang Dipimpin Oleh Hikmat Kebijaksanaan Dalam Permusyawaratan/Perwakilan

5. Keadilan Sosial Bagi Seluruh Rakyat Indonesia

Pendidikan pancasila termasuk mata kuliah yang banyak terkena imbas proses reformasi. Bukan hanya materinya yang banyak berubah. Proses pendidikan juga seharusnya mengalami perubahan mendasar. Perubahan materi pendidikan pancasila menyangkut amandemen 
terhadap UUD 1945 tentang ketatanegaraan dan hak asasi manusia. Perubahan proses perkulihan berkaitan dengan kebebasan yang lebih besar kepada mahasiswa untuk memrefleksikan dan bersikap kritis terhadap implementasi kebijakan pemerintah. Apabila pembatasan ruang gerak pendidikan pancasila terebut dilakukan maka pendidikan pancasila perguruan tinggi tidak akan disukai oleh mahasisiwa. Bagaimana pun juga, mahasiswa dapat menerima informasi dan mendiskusikan informasi tersebut melalui media pendidikan yang beragam diluar perkuliahan. Jika perkulihan pendidikan pancasila dilakukan terbatas, maka ia akan berhadapan dengan situasi luar bergerak secara dinamis.

\section{PEMBAHASAN}

\section{Urgensi Pendidikan Pancasila}

Mata kuliah Pendidikan Pancasila diberikan karena adanya kesadaran akan perlunya pendidikan yang berkesinambungan mulai dari sekolah dasar sampai perguruan tinggi. Diharapkan, dengan pemahaman yang semakin mendalam akan nilai-nilai Pancasila, generasi muda dapat mengimplementasikannya dalam kehidupan sehari-hari,

Pendidikan Pancasila juga diberikan karena fakta kemerosotan penghayatan nilai-nilai Pancasila dalam kehidupan sehari-hari, baik individual maupun kolektif sebagai bangsa. Dengan kata lain, mata kuliah ini dihidupkan karena adanya kesenjangan antara kata/pengetahuan dan perbuatan/tingkah laku.

Kemerosotan penghayatan nilai-nilai Pancasila dapat disaksikan di semua bidang kehidupan, dari semua kelas sosial, dan di hampir semua profesi. Fakta paling jelas adalah korupsi yang dilakukan di semua lini, mulai dari pejabat pemerintah maupun institusi pemerintah dan swasta. Catatan Kementerian Dalam Negeri RI menyebutkan bahwa dalam kurun waktu tahun 2005-2013 ada 277 gubernur, walikota, dan bupati yang terlibat korupsi, dan 3.000 anggota DPRD terjerat hukum. Dalam kurun waktu yang sama terdapat 137 anggota DPRD provinsi dan 1.050 anggota DPRD kabupaten/kota terlibat korupsi (Suara Pembaruan, 9 Desember 2013).

Kasus terbaru yang "mengguncang" seluruh kehidupan bangsa adalah tertangkap tangannya Ketua Mahkamah Konstitusi, Akil Mochtar karena dugaan terlibat suap, merupakan fakta betapa nilai Pancasila hanya menjadi hiasan bibir kala pejabat mengucapkan sumpah jabatan.

Selain kasus korupsi, patut disebutkan beberapa gejala yang mencerminkan kemerosotan penghayatan nilai-nilai Pancasila, seperti kerusuhan dan sengketa berlatarbelakang SARA, kekerasan dalam rumah tangga, kesenjangan ekonomi, ketakmampuan golongan rendah untuk masuk jenjang sekolah dasar hingga perguruan tinggi, berbagai macam dan tingkat kriminalitas, diskriminasi perempuan, dan UU dan peraturan daerah yang tidak sesuai dengan nilai-nilai Pancasila, sekedar menyebut beberapa contoh.

Sistem ekonomi Indonesia yang dalam Pancasila dan UUD 1945 dikenal sebagai demokrasi ekonomi berlandaskan gotong royong, pada praktiknya lebih condong ke sistem ekonomi liberal yang makin memarginalkan kelas bawah. Kesenjangan ekonomi tampak dengan jelas karena dalam sistem liberal seperti ini hanya orang-orang kaya yang tambah kaya, sebaliknya 
orang miskin makin terpuruk. Kekayaan tanah tumpah darah Indonesia yang sebetulnya dikelola untuk kesejahteraan rakyat dikuasai oleh pihak asing dan konco-konconya orangorang kaya.

Pendidikan Pancasila diberikan karena kesadaran akan semakin derasnya arus ideology asing, khususnya kapitalisme dan neoliberalisme, yang berkat sayap raksasa globalisasi menggempur seluruh pelosok Indonesia tanpa henti. Materialisme, hedonism, konsumtivisme, serta gaya hidup yang dibentuknya telah dan sedang menerjang sudut-sudut terpencil Indonesia. Nilai-nilai asing yang sangat digandrungi remaja dan kaum muda itu dikhawatirkan akan semakin melunturkan nilai-nilai Pancasila. Sebab itu dirasakan pendidikan Pancasila sebagai suatu keharusan.

Pendidikan Pancasila bertujuan untuk memberikan pemahaman benar akan Pancasila. Tidak disadari, sering Pancasila yang diajarkan akan Pancasila yang tidak benar, yang merupakan bentuk tersamar dari ideology yang justru bertentangan dengan Pancasila. Oleh sebab itu Pancasila yang diajarkan dalam Pendidikan Pancasila adalah Pancasila yang dapat dipertanggungjawabkan secara juridis-konstitusional dan obyektif-ilmiah. Secara yuridiskonstitusional Pancasila adalah dasar Negara yang merupakan dasar dalam penyelenggaraan pemerintahan Negara. Secara obyektif-ilmiah Pancasila adalah paham filsafat yang dapat diuraikan dan diterima secara rasional.

UU No.20 Tahun 2003 tentang Sistem Pendidikan Nasional, yang diejawantahkan dalam PP No.19 Tahun 2005 tentang Standar Nasional Pendidikan menetapkan kurikulum tingkat Satuan Perguruan Tinggi wajib memuat mata kuliah pendidikan agama, pendidikan kewarganegaraan, dan bahasa Indonesia serta bahasa Inggris. Pendidikan kewarganegaraan memuat pendidikan Pancasila sebagai landasan pengenalan mahasiswa terhadap ideologi negara.

Direktorat Pendidikan Tinggi (Dikti) kemudian, dalam SK No.43/DIKTI/Kep/2006 memutuskan tentang rambu-rmbu Pelaksanan Kelompok Mata Kuliah Pengembangan Kepribadian di Perguruan Tinggi, termasuk di dalamnya Pendidikan Pancasila.

Pertanyaannya: Pancasila yang mana? Pertanyaan ini masuk akal karena Indonesia pernah memiliki tiga UUD, yaini UUD 1945, Konstitusi RIS 1949, dan UUDS 1950 yang memuat Pancasila pada pembukaannya. Agar tidak terjadi kesalahpahaman, dikelurkan Instruksi Presiden (Inpres) No.12 Tahun 1968. Inpres ini menyatakan bahwa Pancasila yang resmi adalah Pancasila yang tata urutan sila-silanya terdapat pada alinea 4 Pembukaan UUD 1945, yang berbunyi:

1. Ketuhanan Yang Maha Esa

2. Kemanusiaan yang adil dan beradab

3. Persatuan Indonesia

4. Kerakyatan yang dipimpin oleh hikmat kebijaksanaan dalam permusyawaratan/perwakilan

5. Keadilan sosial bagi seluruh rakyat Indonesia

\section{. Tujuan Pendidikan Pancasila}

Tujuan pendidikan pancasila dapat dilacak keterkaitannya dengan tujuan nasional dan tujuan pendidikan nasional. Tujuan pendidikan pancasila adalah agar subjek didik memiliki moral yang sesuai dengan nilai pancasila moralitas itu mampu itu terwujud dalam kehidupan sehari-hari (UU No.2 Tahun 1989). Perilaku moral adalah perilaki keimanan dan ketakwaan terhadap tuhan yang maha esa dalam masyarakat yang terdiri dari berbagai agama, perilau 
kemanusian yang adil dan beradap, perilaku yang mendukung persatuan bangsa indonesia. Adapun tujuan pendidikan pancasila diperguruan tinggi adalah agar mahasiswa:

1. Dapat memahami dan mampu melaksanakan jika pancasila dan UUD 1945 dalam kehidupan sebagai warganegara indonesia.

2. Menguasai pengatahuan tentang beragam masalah dasar berkehidupan bermasrakat, berbangsa dan bernegara yang hendak diatasi dengan penerapan pemikiran yang berlandasan pancasila dan UUD 1945.

3. Memupuk sikap dan perilaku yang sesuai dengan nilai-nilai dan norma pancasila, sehingga mampu menanggapi perubahan yang terjadi dalam rangka keterpaduan iptek dan pembangunan.

4. Membantu mahasiswa dalam proses belajar, proses berpikir, memecahkan masalah dan mengambil keputusan dengan menerapkan strategi heuristik terhadap nilai-nilai pancasila.

\section{- Menggali sumber Historis, Sosiologis, Politis Pendidikan Pancasila}

\section{a. Landasan Historis}

Landasan historis adalah landasan-landasan fakta sejarah yang dijadikan dasar bagi pengembangan pendidikan pancasila, baik menyangkut formulasi tujuan, pengembangan materinya, rancangan modal pembelajaranya, dan evaluasinya. Formasi pendidikan pancasila tentu saja tidak hanya memiliki prespektif waktu kebelakang yang berisi alasan-alasan historis perlunya perilaku tertentu bagi generasi muda. Pada dasarnya, tujuan pendidikan pancasila memformulasikan apa yang penting dari masa lampau, masalah yang dihadapi pada sekarang, dan cita-cita tentang kehidupan ideal dimasa lampau.

\section{b. Landasan Sosiologis}

Sosiologi adalah ilmu tentang kehidupan antarmanusia. Didalamnya mengkaji, antara lain latar belakang, susunan dan pola kehidupan sosial dari berbagai golongan dan kelompok masyarakat, disamping juga mengkaji masalah-masalah sosial, perubahan dan pembaharuan dalam masyarakat.

Melalui pendekatan sosiologis ini pula, Anda diharapkan dapat mengkaji struktur sosial, proses sosial, termasuk perubahan-perubahan sosial, dan masalah-masalah sosial yang patut disikapi secara arif dengan menggunakan standar nilai-nilai yang mengacu kepada nilai-nilai Pancasila. Berbeda dengan bangsa-bangsa lain, bangsa Indonesia mendasarkan pandangan hidupnya dalam bermasyarakat, berbangsa, dan bernegara pada suatu asas kultural yang dimiliki dan melekat pada bangsa itu sendiri.

Nilai-nilai kenegaraan dan kemasyarakatan yang terkandung dalam sila-sila Pancasila bukan hanya hasil konseptual seseorang saja, melainkan juga hasil karya besar bangsa Indonesia sendiri, yang diangkat dari nilai-nilai kultural yang dimiliki oleh bangsa Indonesia sendiri melalui proses refleksi filosofis para pendiri negara (Kaelan, 2000: 13). 
Bung Karno menegaskan bahwa nilai-nilai Pancasila digali dari bumi pertiwi Indonesia. Dengan kata lain, nilai-nilai Pancasila berasal dari kehidupan sosiologis masyarakat Indonesia. Pernyataan ini tidak diragukan lagi karena dikemukakan oleh Bung Karno sebagai penggali Pancasila, meskipun beliau dengan rendah hati membantah apabila disebut sebagai pencipta Pancasila, sebagaimana dikemukakan Beliau dalam paparan sebagai berikut:

Makna penting lainnya dari pernyataan Bung Karno tersebut adalah Pancasila sebagai dasar negara merupakan pemberian atau ilham dari Tuhan Yang Maha Kuasa. Apabila dikaitkan dengan teori kausalitas dari Notonegoro bahwa Pancasila merupakan penyebab lahirnya (kemerdekaan) bangsa Indonesia, maka kemerdekaan berasal dari Allah, Tuhan Yang Maha Esa. Hal ini sejalan dengan makna Alinea III Pembukaan UUD 1945. Sebagai makhluk Tuhan, sebaiknya segala pemberian Tuhan, termasuk kemerdekaan Bangsa Indonesia ini wajib untuk disyukuri. Salah satu bentuk wujud konkret mensyukuri nikmat karunia kemerdekaan adalah dengan memberikan kontribusi pemikiran terhadap pembaharuan dalam masyarakat. Bentuk lain mensyukuri kemerdekaan adalah dengan memberikan kontribusi konkret bagi pembangunan negara melalui kewajiban membayar pajak, karena dengan dana pajak itulah pembangunan dapat dilangsungkan secara optimal.

Landasan keberlakuan sosiologis merujuk kepada penerimaan warga masyarakat sebagai sesuatu yang dibutuhkan secara ideology, poltik, ekonomi, social budaya. Pertahanan dan keamanan ( ipoleksosbudhankam ). Dengan penyelenggaraan pendidikan pancasila sesuai dengan kebutuhan manusia ( human needs ). Maka pendidikan pancasila akan berjalan efektif. Sejalan dengan Landasan keberlakuan sosiologis Pancasila diharapkan kita dapat berpartisipasi dalam meningkatkan fungsi-fungsi lembaga pengendalian sosial (agent of social control) yang mengacu kepada nilai-nilai Pancasila.

\section{c. Politisi Pendidikan Pancasila}

Salah satu sumber pengayaan materi pendidikan Pancasila adalah berasal dari fenomena kehidupan politik bangsa Indonesia. Tujuannya agar Anda mampu mendiagnosa dan mampu memformulasikan saran-saran tentang upaya atau usaha mewujudkan kehidupan politik yang ideal sesuai dengan nilai-nilai Pancasila. Bukankah Pancasila dalam tataran tertentu merupakan ideologi politik, yaitu mengandung nilai-nilai yang menjadi kaidah penuntun dalam mewujudkan tata tertib sosial politik yang ideal. Hal tersebut sejalan dengan pendapat Budiardjo (1998:32) sebagai berikut: "Ideologi politik adalah himpunan nilai-nilai, idée, norma-norma, kepercayaan dan keyakinan, suatu "Weltanschauung", yang dimiliki seseorang atau sekelompok oran, atas dasar mana dia menentukan sikapnya terhadap kejadian dan problema politik yang dihadapinya dan yang menentukan tingkah laku politiknya." 
Melalui pendekatan politik diharapkan mampu menafsirkan fenomena politik dalam rangka menemukan pedoman yang bersifat moral yang sesuai dengan nilai-nilai Pancasila untuk mewujudkan kehidupan politik yang sehat. Pada gilirannya, Anda akan mampu memberikan kontribusi konstruktif dalam menciptakan struktur politik yang stabil dan dinamis.

Secara spesifik, fokus kajian melalui pendekatan politik tersebut, yaitu menemukan nilai-nilai ideal yang menjadi kaidah penuntun atau pedoman dalam mengkaji konsep-konsep pokok dalam politik yang meliputi negara (state), kekuasaan (power), pengambilan keputusan (decision making), kebijakan (policy), dan pembagian (distribution) sumber daya negara, baik di pusat maupun di daerah. Melalui kajian tersebut, Anda diharapkan lebih termotivasi berpartisipasi memberikan masukan konstruktif, baik kepada infrastruktur politik maupun suprastruktur politik.

\section{Argumen Tentang Dinamika dan Tantangan Pancasila}

Indonesia, terhampar dari Sabang hingga Marauke. Seperti yang diketahui bersama, Indonesia sebagai negara kepulauan terbentuk dari keberagaman suku, adat-istiadat, dan bahasa. Dengan kondisi sosial budaya Indonesia yang begitu heterogen, pandangan hidup atau ideologi sebagai sebuah dasar negara menjadi praktis sangat dibutuhkan. Indonesia membutuhkan sebuah ideologi netral yang bisa memayungi dan merangkul semua budaya dari berbagai lapisan masyrakat. Akan tetapi sebelum kita membahas makalah ini, sebenarnya apa itu ideologi?

Secara harfiah, menurut kamus umum bahasa Indonesia ideologi adalah sebuah sistem kepercayaan yang menerangkan, membenarkan suatu tatanan yang ada/yang dicita-citakan dan memberikan strategi berupa prosedur, rancangan, instruksi, serta program untuk mencapainya. Di pihak yang sama, Shawn T. \&Sunshine H. (2005) membenarkan bahwa ideologi adalah sebuah sistem pandangan umum tentang sesuatu hal.

Penulis menyimpulkan bahwa jelas sekali ideologi adalah sebuah pandangan berupa tujuan yang ingin diacapai oleh sebuah kelompok tertentu yang memiliki kesamaan. Sebuah ideologi sebagai pemersatu bangsa yang ada di Indonesia tidak lain adalah Pancasila, sebuah sistem yang dari awal di cetuskan telah menjadi sebuah dasar dari berbagai aspek kehidupan bangsa. Pancasila yang terjabar secara konstitusional telah menjadi asas normatif-filosofis-ideologiskonstitusional bangsa, yang menjadi dasar dari cita budaya dan moral politik nasional (Dwirini, A. 2011).

Lebih dari 66 tahun yang lalu, sejarah Pancasila pada awal-mulanya dibentuk. Diawali ketika pada tanggal 29 April 1945, kaisar Jepang sedang memperingati hari lahirnya. Penjajah jepang berjanji akan memberikan kemerdekaan terhadap bangsa Indonesia. Janji ini diberikan dikarenakan Jepang yang sedang terdesak oleh tentara sekutu. Untuk mendapatkan simpati dan dukungan bangsa Indonesia, bangsa indonesia boleh memperjuangkan kemerdekaannya. Untuk mengawalinya, jepang membentuk sebuah badan yang bertujuan untuk menyelidiki 
usaha-usaha persiapan kemerdekaan Indonesia yaitu Badan Penyelidik Usaha Persiapan Kemerdekaan Indonesia (BPUPKI). Jepang memilih ketua (kaicoo) Dr. KRT. Rajiman Widyodiningrat yang kemudian mengusulkan agenda sidang membahas tentang dasar negara. Pada tanggal 1 Juni, Ir. Soekarno pertama kali mengusulkan istilah Pancasila sebagai dasar negara dan disahkannya Pancasila pada tanggal 18 Agustus 1945 merupakan terobosan gemilang mengenai dasar negara oleh para founding fathers pada masa itu.

Sejalan dengan berjalannya sebuah negara Indonesia, ideologi Pancasila yang terbentuk mengalami ujian dan dinamika dari sebuah sistem politik. Dimulai dengan sistem demokrasi liberal yang dianut pada masa setelah indonesia merdeka, pembentukan indonesia serikat, sistem liberal pada UUDS 1945, dan peristiwa G 30 S PKI.

Menurut Prof. Dr. B.J. Habibie yang seperti dikutip dalam Metro TV news.com bahwa sejak jaman demokrasi parlementer, terpimpin, orde baru dan demokrasi multipartai pancasila harus melewati alur dialektika peradaban yang menguji ketangguhannya sebagai dasar filosofis bangsa Indonesia yang terus berkembang dan tak pernah berhenti di satu titik terminal sejarah.

Dengan sejarah perjuangan pancasila dari awal dibentuknya seperti disebutkan di atas, pancasila membuktikan diri sebagai cara pandang dan metode ampuh bagi seluruh bangsa Indonesia untuk membendung trend negatif perusak asas berkehidupan bangsa. Tantangan yang dahulu dihadapi oleh Pancasila sebagai dasar negara, jenis dan bentuknya sekarang dipastikan akan semakin kompleks dikarenakan efek globalisasi. Globalisasi menurut Ahmad, M. (2006) adalah perkembangan di segala jenis kehidupan dimana batasanbatasan antar negara menjadi pudar dikarenakan perkembangan ilmu pengetahuan dan teknologi (IPTEK). Berkembangnya arus informasi menjadi sebuah ciri spesifik dari terminologi globalisasi. Setiap warga negara akan semakin mudah dan bebas untuk mengakses berbagai jenis informasi dari berbagai belahan dunia manapun dalam waktu yang sangat singkat.

Dengan perkembangan Informasi yang begitu cepat, tantangan yang diterima oleh ideologi pada saat ini juga menjadi sangat luas dan beragam. Sebagai contoh, beragamnya banyak agama di Indonesia yang terkadang menjadi alasan pemicu konflik horizontal antar umat beragama, ekonomi yang mulai berpindah dari sistim kekeluargaan (contoh: pasar tradisional) menjadi sistem kapitalisme dimana keuntungan merupakan tujuan utama, paham komunisme, liberalisme, terorisme, chauvinisme, dsb. Masih banyak lagi hal dalam kehidupan warga negara indonesia yang dipengaruhi oleh informasi yang begitu mudah dan cepat tersebut, tanpa bisa di sebutkan satu-persatu. Masalah-masalah yang disebutkan diatas bertentangan dengan semua nilai yang terkandung dalam pancasila sebagai dasar negara.

Lalu sebenarnya apa fungsi Pancasila sebagai dasar negara? Peran pancasila yang pertama pada dasarnya adalah Pancasila digunakan sebagai penyaring informasi yang beragam. Bahwa kita memiliki budaya dan pedoman yang harus tetap dijaga sebagai sebuah identitas bahwa kita adalah bangsa indonesia. Jika sebuah warga negara tertutup, pastinya warga 
negara tersebut akan tertinggal jauh oleh perkembangan informasi yang begitu cepat. Pancasila menjaga nilai-nilai normatif-filosofis-ideologis bangsa Indonesia agar tetap sejalan dengan perkembangan ilmu pengetahuan dan teknologi yang terjadi pada era globalisasi sekarang ini. Pancasila seharusnya juga menjadi batasan pandangan yang seharusnya dimiliki oleh setiap warga negara. Banyak kalangan yang lupa akan budaya dan bahasa daerah dikarenakan pengaruh globalisasi yang sangat hebat, sehingga mengikis ide tentang jati diri bangsa sebagai bangsa Indonesia. Batasan pandangan yang sesuai menurut Pancasila seharusnya menjadi garis bawah bahwa kita seharusnya boleh mengikuti perkembangan zaman, akan tetapi ada beberapa batasan-batasan nilai yang harus dijunjung, yaitu nilai-nilai yang terkandung dalam pancasila. Akan tetapi, fungsi-fungsi tersebut sekarang ini sudah mulai dilupakan oleh kalangan masyarakat Indonesia. Hal ini dikarenakan perubahan yang terjadi pada lingkungan dan situasi kehidupan bangsa Indonesia di semua level wilayah.

Prof. Dr. B.J. Habibie menuturkan bahwa lenyapnya Pancasila dari kehidupan terkait beberapa hal. Pertama, situasi dan lingkungan kehidupan bangsa yang telah berubah baik di tingkat domestik, regional maupun global. Perubahan tersebut telah mendorong terjadinya pergeseran nilai yang dialami bangsa Indonesia termasuk dalam corak perilaku kehidupan politik dan ekonomi yang terjadi saat ini. Kedua, alasan selanjutnya mengapa Pancasila sudah mulai dilupakan adalah terjadinya euforia reformasi sebagai akibat traumatik masyarakat terhadap penyalahgunaan kekuasaan di masa lalu yang mengatasnamakan Pancasila. Trauma atas gerakan G30S/PKI yang selanjutnya di lakukan rezim orde baru yaitu menjadikan Pancasila sebagai alat untuk mempropaganda masyarakat, juga menjadi salah satu alasan mengapa pancasila sudah mulai dilupakan.

Lalu bagaimana cara menghadapi tantangan sudah mulai memudarnya rasa memiliki warga negara dari setiap nilai-nilai pancasila? hal ini dapat dilakukan dengan menyadarkan kembali, reaktualisasi nilai-nilai tersebut dalam konteks peri kehidupan sehari-hari bangsa Indonesia, tetap berpegang teguh pada nilai-nilai pancasila, dan penanaman kembali ide tentang Pancasila sebagai dasar negara sejak dini. Bukan hanya tanggung jawab pemerintah akan tetapi sudah merupakan tanggung jawab kita bersama, membantu mengatasi Pancasila dalam menghadapi tantangannya di era global sekarang ini. Walaupun banyak tantangan dalam mempertahankan Pancasila sebagai dasar negara, Pancasila telah membuktikan bahwa Pancasila bukan merupakan milik golongan tertentu atau representasi dari suku tertentu. Pancasila itu netral dan akan selalu hidup di segala zaman seperti yang telah dilewati di tahun-tahun sebelumnya.

\section{Essensi dan urgensi pendidikan pancasila untuk masa depan}

Generasi penerus melalui Pendidikan Pancasila dan Kewarganegaraan diharapkanakan mampu mengantisipasi hari depan yang senantiasa berubah dan selalu terkait dengan konteks dinamika budaya, bangsa, negara, dalam hubungan internasional serta 
memiliki wawasan kesadaran bernegara untuk bela negara dan memiliki pola pikir, pola sikap dan perilaku yang cinta tanah air berdasarkan Pancasila. Semua itu diperlakukan demi tetap utuh dan tegaknya Negara Kesatuan Republik Indonesia.Tujuan utama Pendidikan Pancasila dan Kewarganegaraan adalah untuk menumbuhkan wawasan dan kesadaran bernegara, sikap serta perilaku yang cinta tanah air, wawasan nusantara, serta ketahanan nasional dalam diri warga negara Republik Indonesia. Selain itu bertujuan untuk meningkatkan kualitas manusia Indonesia yang berbudi luhur, berkepribadian, mandiri, maju, tangguh, cerdas, kreatif, terampil, berdisiplin, beretos kerja, profesional, bertanggung jawab, dan produktif serta sehat jasmani dan rohani.

Pengembangan nilai, sikap, dan kepribadian diperlukan pembekalan kepada peserta didik di Indonesia yang diantaranya dilakukan melalui Pendidikan Pancasila, Pendidikan Agama, Ilmu Sosial Dasar, Ilmu Budaya Dasar, dan Ilmu Alamiah Dasar (sebagai aplikasi nilai dalam kehidupan) yang disebut kelompok Mata Kuliah Pengembangan Kepribadian (MKPK) dalam komponen kurikulum perguruan tinggi. Hak dan kewajiban warga negara, terutama kesadaran bela negaraakan terwujud dalam sikap dan perilakunya bila ia dapat merasakan bahwa konsepsi demokrasi dan hak asasi manusia sungguh- sungguh merupakan sesuatu yang paling sesuai dengan kehidupannya sehari-hari.

Pendidikan Pancasila dan Kewarganegaraan yang berhasil akan membuahkan sikap mental yang cerdas, penuh rasa tanggung jawab dari peserta didik. Sikap ini disertai dengan perilaku yang :

1. Beriman dan bertakwa kepada Tuhan Yang Maha Esa serta menghayati nilai-nilai falsafah bangsa

2. Berbudi pekerti luhur, berdisiplin dalam bermasyarakat, berbangsa dan bernegara.

3. Rasional, dinamis, dan sadar akanhak dan kewajiban sebagai warga negara.

4. Bersifat profesional yang dijiwai oleh kesadaran bela negara.

5. Aktif memanfaatkan ilmu pengetahuan teknologi dan seni untuk kepentingan kemanusiaan, bangsa dan negara.

Melalui Pendidikan Pancasila dan Kewarganegaraan, warga negara Republik Indonesia diharapkan mampu "memahami, menganalisa, dan menjawab masalah-masalah yang dihadapi oleh masyarakat, bangsa dan negaranya secara konsisten dan berkesinambungan dengan cita-cita dan tujuan nasional seperti yang digariskan dalam Pembukaan UUD 1945 “. Dalam perjuangan non fisik, harus tetap memegang teguh nilai-nilai ini disemua aspek kehidupan, khususnya untuk memerangi keterbelakangan, kemiskinan, kesenjangan sosial, korupsi, kolusi, dan nepotisme; menguasai IPTEK, meningkatkan kualitas sumber daya manusia agar memiliki daya saing; memelihara serta menjaga persatuan dan kesatuan bangsa; dan berpikir obyektif rasional serta mandiri. 


\section{PENUTUP}

\section{Kesimpulan}

Berdasarkan uraian disusun dalam makalah ini maka penulis menyampaikan bahwa pendidikan pancasila sangat dibutuhkan dalam berbagai kalangan untuk mewujudkan suatu bangsa dan Negara yang mampu membanggakan pancasila sebagai landasan utama dalam kehidupan berbangsaan bernegara pada khususnya. Oleh karena itu dengan penyusunan makalah ini semoga dapat berguna bagi para pembaca sebagai acuan proses pembelajaran dalam menjawab segala tantangan yang ada.

saran

Dalam membuat Menelusuri Konsep Dan Urgensi Pendidikan Pancasila ini mungkin masih terdapat kesalahan - kesalahan, sehingga kami mengaharapkan kritik dari pembaca agar makalah yang kami buat ini menjadi lebih baik dan lebih sempurna. 


\section{DAFTAR PUSTAKA}

Darmini Roza dan Laurensius Arliman S Peran Pemerintah Daerah Di Dalam Melindungi Hak Anak Di Indonesia, Masalah-Masalah Hukum, Volume 47, Nomor 1, 2018.

Laurensius Arliman S, Komnas HAM dan Perlindungan Anak Pelaku Tindak Pidana, Deepublish, Yogyakarta, 2015.

Laurensius Arliman S, Penguatan Perlindungan Anak Dari Tindakan Human Trafficking Di Daerah Perbatasan Indonesia, Jurnal Selat, Volume 4, Nomor 1, 2016.

Laurensius Arliman S, Problematika Dan Solusi Pemenuhan Perlindungan Hak Anak Sebagai Tersangka Tindak Pidana Di Satlantas Polresta Pariaman, Justicia Islamica, Volume 13, Nomor 2, 2016.

Laurensius Arliman S, Pelaksanaan Perlindungan Anak Yang Tereksploitasi Secara Ekonomi Oleh Pemerintah Kota Padang, Veritas et Justitia, Volume 2, Nomor 1, 2016.

Laurensius Arliman S, Kedudukan Ketetapan MPR Dalam Hierarki Peraturan Perundang-Undangan Di Indonesia,Lex Jurnalica, Volume 13, Nomor 3, 2016.

Laurensius Arliman S, Komnas Perempuan Sebagai State Auxialiary Bodies Dalam Penegakan Ham Perempuan Indonesia, Justicia Islamica, Volume 14, Nomor 2, 2017.

Laurensius Arliman S, Peranan Pers Untuk Mewujudkan Perlindungan Anak Berkelanjutan Di Indonesia, Jurnal Ilmu Hukum Tambun Bungai, Volume 2, Nomor 2, 2017.

Laurensius Arliman S, Mewujudkan Penegakan Hukum Yang Baik Untuk Mewujudkan Indonesia Sebagai Negara Hukum, Jurnal Hukum Doctrinal, Volume 2, Nomor 2, 2017. 
Laurensius Arliman S, Participation Non-Governmental Organization In Protecting Child Rights In The Area Of Social Conflict, The 1st Ushuluddin and Islamic Thought International Conference (Usicon), Volume 1, 2017.

Laurensius Arliman S, Partisipasi Masyarakat Dalam Pembentukan Perundang Undangan Untuk Mewujudkan Negara Kesejahteraan Indonesia, Jurnal Politik Pemerintahan Dharma Praja, Volume 10, Nomor 1, 2017, https://doi.org/10.33701/jppdp.v10i1.379.

Laurensius Arliman S, Peran Komisi Perlindungan Anak Indonesia Untuk Mewujudkan Perlindungan Anak, Jurnal Respublica Volume 17, Nomor 2, 2018.

Laurensius Arliman S, Menjerat Pelaku Penyuruh Pengrusakan Barang Milik Orang Lain Dengan Mempertimbangkan Asas Fungsi Sosial, Jurnal Gagasan Hukum, Volume 1,Nomor 1, 2019.

Laurensius Arliman S, Ilmu Perundang-Undangan Yang Baik Untuk Negara Indonesia, Deepublish, Yogyakarta, 2019.

Laurensius Arliman S, Isdal Veri, Gustiwarni, Elfitrayenti, AdeSakurawati, Yasri, Pengaruh Karakteristik Individu, Perlindungan Hak Perempuan Terhadap Kualitas Pelayanan Komnas Perempuan Dengan Kompetensi Sumber Daya Manusia Sebagai Variabel Mediasi, Jurnal Menara Ekonomi: Penelitian dan Kajian Ilmiah Bidang Ekonomi, Volume 6, Nomor 2, 2020.

Laurensius Arliman S, Pendidikan Kewarganegaraan, Deepublish, Yogyakarta, 2020.

Laurensius Arliman S, Makna Keuangan Negara Dalam Pasal Pasal 23 E Undang-Undang Dasar 1945, Jurnal Lex Librum, Volume 6, Nomor 2 Juni 2020, http://dx.doi.org/10.46839/1ljih.v6i2.151.

Laurensius Arliman S, Kedudukan Lembaga Negara Independen Di Indonesia Untuk Mencapai Tujuan Negara Hukum, Kertha Semaya Journal Ilmu Hukum, Volume 8, Nomor 7, 2020.

Laurensius Arliman S, Pelaksanaan Assesment Oleh Polres Kepulauan Mentawai Sebagai Bentuk Pelaksanaan Rehabilitasi Bagi Pecandu Dan Korban Penyalahgunaan Narkotika, Jurnal Muhakkamah, Volume 5, Nomor 1, 2020.

Laurensius Arliman S, Aswandi Aswandi, Firgi Nurdiansyah, Laxmy Defilah, Nova Sari Yudistia, Ni Putu Eka, Viona Putri, Zakia Zakia, Ernita Arief, Prinsip, Mekanisme Dan Bentuk Pelayanan Informasi Kepada Publik Oleh Direktorat Jenderal Pajak, Volume 17, No Nomor, 2020.

Larensius Arliman S, Koordinasi PT. Pegadaian (Persero) Dengan Direktorat Reserse Narkoba Polda Sumbar Dalam Penimbangan Barang Bukti Penyalahgunaan Narkotika, UIR Law Review, Volume 4, Nomor 2, 2020, https://doi.org/10.25299/uirlrev.2020.vol4(1).3779.

Laurensius Arliman S, Tantangan Pendidikan Kewarganegaraan Pada Revolusi 4.0, Ensiklopedia Sosial Review, Volume 2, Nomor 3, 2020. 
Muhammad Afif dan Laurensius Arliman S, Protection Of Children's Rights Of The Islamic And Constitutional Law Perspective Of The Republic Of Indonesia, Proceeding: Internasional Conference On Humanity, Law And Sharia (Ichlash), Volume 1, Nomor 2, 2020.

Otong Rosadi danLaurensius Arliman S, Urgensi Pengaturan Badan Pembinaan Idelogi Pancasila Berdasarkan Undang-Undang Sebagai State Auxiliary Bodies yang Merawat Pancasila dalam Perspektif Hak Asasi Manusia, Prosiding Konferensi Nasional Hak Asasi Manusia, Kebudayaan dan Tujuan Pembangunan Berkelanjutan Indonesia pada Masa Pandemi Covid-19: Tantangan untuk Keilmuan Hukum dan Sosial Volume 1, Universitas Pancasila, Jakarta, 2020. 